Vol. 1 No. 2 September 2021 e-ISSN : 2797-3344 P-ISSN : 2797-3336

\title{
PENERAPAN MODEL PEMBELAJARAN COOPERATIVE LEARNING MELALUI TIPE TGT (TEAMS GAMES TOURNAMENT) UNTUK MENINGKATKAN PRESTASI BELAJAR AQIDAH AKHLAK KD MEMAHAMI TASAWUF KELAS XI IPS1 MAN 1 JOMBANG
}

\author{
IDA INAYAHWATI \\ MAN 1 Jombang \\ Email : idainayahwati2394@gmail.com
}

\begin{abstract}
ABSTRAK
Penelitian ini bertujuan untuk meningkatkan prestasi belajar siswa pada mata pelajaran Aqidah Akhlak khususnya KD Memahami Tasawuf. Penilaian pada materi tasawuf ini bukan hanya padah ranah pengetahuan (kognitif) melainkan mencakup seluruh ranah sikap (ada perubahan sikap) dan Ketrampilan (penerapan pemahaman religi) pada setiap siswa. Karena itulah peneliti merumuskan strategi yang dapat membangkitkan prestasi belajar siswa, dimana dalam kegiatan pembelajaran ini selain mampu mencapai seluruh aspek yang diharapkan siswa juga mampu menanamkan sifat social dalam diri mereka masing-masing. Strategi pembelajaran yang ditawarkan adalah pembelajaran kooperatif (Cooperative Learning Strategy), yaitu dengan menggunakan tipe Teams Games Tournament (TGT). Dilakukan pada kelas XI IPS1 MAN 1 Jombang. Penelitian dengan menggunakan model pembelajaran cooperative learning melalui tipe TGT (Teams Games Tournaments) ini dilakukan dalam dua kali siklus, masing-masing terdiri dari dua kali pertemuan tatap muka. Sebelum melakukan tindakan penelitian, peneliti melakukan pre test terlebih dahulu pada kelas yang diteliti (sebelum diterapkannya strategi pembelajaran kooperatif, pada pret test ini didapatkan hasil nilai yang didapat siswa pada materi ini dengan rata-rata 79. Selanjutnya setelah model pembelajaran cooperative learning melalui tipe TGT (Teams Games Tournaments) maka pada siklus kedua diperoleh rata-rata ketruntasan belajar 84, dan pada siklus ke tiga peningkatan nilai rata-rata mejadi 95, sangat signifikan.

Kata kunci : Cooperative Learning, Metode Teams Games Tournament, Prestasi Belajar Akidah Akhlak, dan Tasawuf.
\end{abstract}

\section{ABSTRACT}

This study aims to improve student achievement in Aqidah Akhlak subjects, especially KD Understanding Sufism. The assessment of this Sufism material is not only in the realm of knowledge (cognitive) but includes the entire domain of attitude (there is a change in attitude) and skills (application of religious understanding) for each student. That's why researchers formulate strategies that can generate student achievement, where in this learning activity, apart from being able to achieve all the aspects that are expected, students are also able to instill social traits in each of them. The learning strategy offered is cooperative learning (Cooperative Learning Strategy), namely by using the Team Games Tournament (TGT) type. Conducted in class XI IPS1 MAN 1 Jombang. This research was conducted in two cycles, each consisting of two face-to-face meetings. Before carrying out the research action, the researcher conducted a pre-test in the class being studied (before the implementation of cooperative learning strategies, in this pret test the results obtained by students on this material with an average of 79 . Furthermore, after the cooperative learning model through the TGT type (Teams Games Tournaments) then in the second cycle obtained an average learning completeness of 84 , and in the third cycle the increase in the average score became 95, very significant.

Keywords: Cooperative Learning, Teams Games Tournament Method, Learning Achievement of Akidah Akhlak, and Sufism.

\section{PENDAHULUAN}

Pendidikan Agama Islam saat ini khususnya Aqidah Akhlak masih sangat jauh dari harapan atau tujuan pendidikan nasional, Pembelajaran lebih menitikberatkan pada aspek 


\section{Vol. 1 No. 2 September 2021 e-ISSN : 2797-3344 P-ISSN : 2797-3336}

korespondensi tekstual yang lebih menekankan hafalan teks-teks keagamaan, dan terkesan hanya pada pengembangan pada ranah kognitif. Selama ini, metodologi pembelajaran agama Islam khususnya mata pelajaran Akidah Akhlak, yang diterapkan masih mempertahankan caracara lama (tradisional) seperti ceramah, menghafal dan demonstrasi praktik-praktik ibadah yang tampak kering. Model-model pembelajaran seperti ini masih belum efektif untuk ketercapaian tujuan pembelajaran dan peningkatan prestasi belajar siswa.

Pada ruang lingkup Kompetensi Inti dan Kompetensi Dasar Aqidah Akhlak, pembahasan Tasawuf terdapat dalam KI-KD materi pelajaran kelas XI (reguler) semester Ganjil. Jadi Tasawuf bukan berdiri sendiri dalam satu mata pelajaran di tingkat Madrasah Aliyah, melainkan terintegrasi dalam mata pelajaran Aqidah Akhlak. Disinilah vokus penelitian dilakukan. Dengan mengambil kelas XI IPS1 sebagai obyek peneliatian.

Awal masuk kelas XI IPS1, siswa cukup terlihat kurang bersemangat dalam mengikuti pelajaran. Hal itu terlihat dari kurangnya rasa ingin tahu mereka terhadap materi yang akan diberikan. Kebanyakan dari mereka kelihatannya jenuh terhadap pelajaran. Dari hasil evaluasi pada saat pre test, didapatkan rata-rata prestasi belajar kelas sebesar 79, hal ini karena ada beberapa kendala, seperti siswa belum memiliki buku pegangan/buku paket aqidah akhlak, siswa masih ramai dan belum pernah konsentrasi pada materi, dan siswa kurang disiplin dalam mengerjakan tugasnya, yaitu mereka setengah-setengah dalam mengerjakan tugas.

Berangkat dari pengalaman inilah, kemudian peneliti memunculkan ide untuk menggunakan strategi Pengajaran Teams Games Tournament. Sebuah pembelajaran yang tidak hanya memerintahkan siswa untuk mendengar dan memahami materi, akan tetapi siswa juga diajak untuk bermain dan belajar untuk berinteraksi dengan teman satu kelas. Dalam kegiatan ini siswa terlihat lebih aktif jika dibandingkan dengan metode sebelumnya yaitu metode ceramah.

Materi Tasawuf memang punya karakter tersendiri, seperti dikemukakan oleh H.A. Mustafa (2005) bahwa hakikat tasawuf adalah kehidupan rohani yang merupakan fitrah manusia dengan tujuan untuk mencapai hakikat yang tinggi, berada dekat atau sedekat mungkin dengan Allah dengan cara menyucikan jiwanya, dengan melepaskan jiwanya dan kungkungan jasadnya yang hanya terkontaminasi oleh kehidupan benda serta melepaskan jiwanya dari nodanoda sifat dan perbuatan jelek. Memutus setiap ajakan gejolak syahwat dan meninggalkan kemewahan dunia atau hal-hal yang dianggap baik serta kecenderungan pada hal-hal yang biasa berjalan di tengah kehidupan.

Esensi dari ajaran tasawuf seperti dituliskan oleh Inayahwati (2017) adalah tekun beribadah, berhubungan langsung dengan Allah menjauhkan diri dari kemewahan dunia, tidak suka dari apa yang diburu orang banyak mulai dari kenikmatan, harta benda dan kedudukan, dan menyendiri dalam kesunyian untuk beribadah kepada Allah.

Dijelaskan pada Al-Quran surah At-Tahrim ayat 8 yang artinya bahwa:

"Wahai orang-orang yang beriman! Bertobatlah kepada Allah dengan Tobat yang semurni-murninya, mudah-mudahan Tuhan kamu akan menghapus kesalahan- pada hari ketika Allah tidak mengecewakan Nabi dan orang-orang yang beriman bersama kesalahanmu dan memasukanmu dalam surga-surga yang mengalir di bawahnya sungai-sungai, dengannya: sedang cahaya mereka memancar di hadapan disebelah kanan mereka, sambil mereka mengatakan: sempurnakanlah bagi kami cahaya kami, dan ampunilah kami: sungguh Engkau Mahakuasa atas segala sesuatu”

Begitu luhur dan sempurnanya essensi dari pengertian tasawuf ini, maka tentunya perlu memilih strategi dan metode yang sangat tepat, efektif dan efisien dalam kegiatan pembelajaran Aqidah Akhlak pada materi Tasawuf ini sehingga prestasi belajar siswa akan meningkat secara signifikan.

Untuk itu dalam pemilihan metode diperlukan beberapa pertimbangan oleh guru diantaranya Tujuan yang akan dicapai, bahan atau materi yang akan diajarkan, keadaan anak atau murid yang akan menerima pelajaran, kemampuan guru yang akan menggunakan metode, 


\section{Vol. 1 No. 2 September 2021 e-ISSN : 2797-3344 P-ISSN : 2797-3336}

prasarana dan sarana yang tersedia dan situasi dan lingkungan dimana anak akan melaksanakan kegiatan belajar.

Dari beberapa pertimbangan tersebut, guru akan bisa dengan tepat memilih startegi yang akan dicapai. Perlu diketahui bahwa tidak satu metode pun yang selalu harus dipertahankan kemutlakannya, dan memang memerlukan sistem penggabungan antara beberapa metode. Bisa dikatakan apabila ada salah satu metode berhasil diterapkan di salah satu sekolah, maka belum pasti metode tersebut berhasil jika diterapkan kepada sekolah lain.

Salah satu tipe atau model yang dapat dipakai untuk mencapai keberhasilan dalam kegiatan pembelajaran adalah Teams Games Tournament yang merupakan salah satu variasi model cooperative learning.

Cooperative learning sebagaimana dikemukakan Slavin (2010) berasal dari kata cooperative yang artinya mengerjakan sesuatu secara bersama-sama dengan saling membantu satu sama lainnya sebagai satu kelompok atau satu tim. Menurut Kauchak dan Eggen dalam Suradi (2006) belajar kooperatif merupakan suatu kumpulan strategi mengajar yang digunakan untuk membantu siswa satu dengan siswa yang lain dalam mempelajari sesuatu. Isjoni (2007:15) juga mengungkapkan bahwa: Cooperative learning adalah suatu model pembelajaran dimana sistem belajar dan bekerja dalam kelompok-kelompok kecil yang berjumlah 4-6 orang secara kolaboratif sehingga dapat merangsang siswa lebih bergairah dalam belajar. Pembelajaran kooperatif dikenal adanya beberapa tipe, salah satu diantaranya tipe TGT. Menurut Wina Sanjaya (2008) mengatakan bahwa Pembelajaran kooperatif tipe TGT adalah suatu pembelajaran dimana setelah kehadiran guru, siswa pindah ke kelompoknya masing-masing untuk saling membantu menjawab pertanyaan-pertanyaan dari materi yang diberikan. Setiap siswa akan bertemu pada meja turnamen untuk berlomba. Mereka menjawab satu pertanyaan yang sama yang telah dibahas bersama-sama dalam kelompoknya. Dengan cara ini setiap siswa berkesempatan menyumbangkan skor sebanyak-banyaknya untuk kelompoknya. Kelompok yang memiliki skor tertinggi itulah yang menjadi pemenang turnamen.

Metode turnamen belajar merupakan salah satu bentuk yang disederhanakan dari teams games tournaments. Metode ini dikembangkan oleh Robert Slavin dan kawannya. Metode ini juga menggabungkan kelompok belajar dan kompetensi tim dan dapat digunakan untuk pengembangan pelajaran bermacam-macam fakta, konsep, dan keterampilan.

Melvin L.S (2006:171) mengemukakan langkah-langkah dalam pelaksanaan metode turnamen belajar adalah sebagai berikut:

a. Membagi siswa dalam tim yang beranggotakan 4-5 orang. Masing-masing tim terdiri dari laki-laki dan perempuan dengan kemampuan akademik yang beragam.

b. Memberikan materi kepada tim untuk dipelajari bersama.

c. Mengembangkan beberapa pertanyaan untuk menguji pemahaman dan atau pengingatan akan materi pelajaran dengan menggunakan format yang memudahkan penilaian sendiri misalnya pilihan ganda, mengisi titik-titik benar/ salah, atau definisi istilah.

d. Memberikan pertanyaan kepada siswa dan menyebutnya sebagai "ronde satu" dari turnamen belajar. Setiap siswa harus menjawab pertanyaan.

e. Setelah pertanyaan diberikan, guru menyediakan jawabannya dan memerintahkan siswa untuk menghitung jumlah pertanyaan yang mereka jawab dengan benar. Selanjutnya meminta mereka untuk menyatukan skor mereka dengan tiap anggota tim mereka untuk mendapatkan skor tim. Kemudian mengumumkan skor dari tiap tim.

f. Meminta tim untuk belajar lagi untuk "ronde ke-2" dalam turnamen kemudian mengajukan pertanyaan lagi sebagai bagian dari ronde ke-2 dan meminta tim untuk sekali lagi menggabungkan skor mereka dan menambahkannya ke skor mereka di ronde pertama.

g. Guru dapat melakukan beberapa ronde sebanyak yang dipilih namun pastikan untuk memberi kesempatan tim untuk menjalani sesi belajar antara masing-masing ronde (lama turnamen belajar bia sa bervariasi, bisa singkat selama 20 menit atau beberapa jam). 


\section{METODE PENELITIAN}

Dalam melaksanakan tindakan Penelitian siswa kelas XI IPS1 MAN 1 Jombang, dengan jumlah ssiwa 36, mulai tanggal 5 januari 2019 sampai denganb 19 Pebruari 2019, peneliti melakukan pengamatan (observasi) dan pencatatan pada perkembangan yang terjadi. Yaitu mengamati kejadian-kejadian saat pembelajaran berlangsung. Observasi dilakukan dengan terstruktur, terfokus dan sistematik

Data yang diperoleh dari Penelitian Tindakan Kelas yang telah dilaksanakan oleh peneliti ini akan dianalisis untuk memastikan bahwa dengan menggunakan metode Teams Games Tournament dapat meningkatkan prestasi belajar siswa-siswi kelas XI IPS 1 MAN 1 Jombang terhadap mata pelajaran Akidah Akhlak. Peneliti menganalisa dan merefleksi hasil tindakan dan mendiskusikannya dengan guru pamong mata pelajaran Akidah Akhlak serta merespon permasalahan baru yang muncul di luar perencanaan untuk dilanjutkan pada siklus berikutnya. Refleksi dilakukan dengan mempertimbangkan berhasil dan tidaknya tindakan serta memberikan arah bagi perbaikan selanjutnya.

Lebih jelasnya bisa diperhatikan pada bagan tahap penelitian mengikuti model dari Kemmis-McTaggart (diadopsi dalam Wahidmurni, 2008;42) berupa suatu siklus yang meliputi kegiatan perencanaan, pelaksanaan tindakan, obsevasi, dan refleksi.

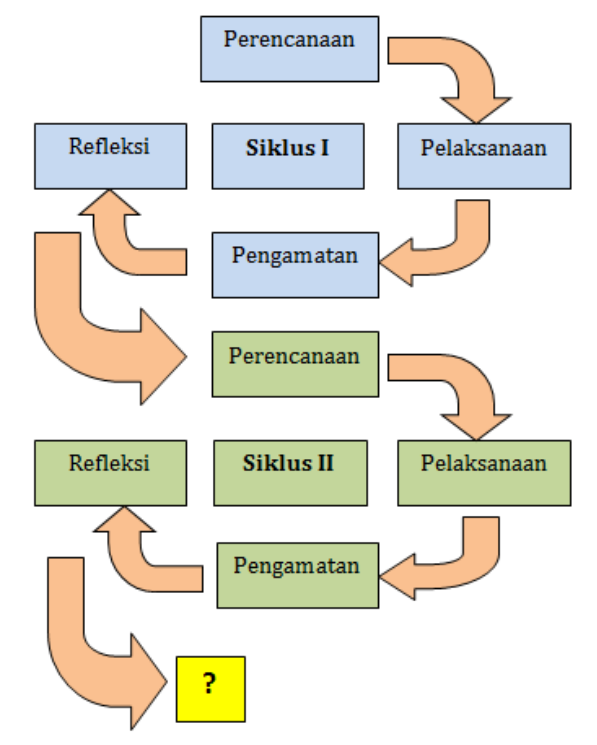

\section{Gambar 1 ; Model Siklus Kegiatan Penelitian oleh Kemmis}

Pada pembelajaran yang dilakukan dengan stategi Teams Games Tournament ini masih sangat asing bagi siswa, oleh sebab itu peneliti yang sekaligus menjadi pengajar memberikan kisi-kisi yang jelas ditambahkan dengan metode yang sudah dikenal siswa, agar nantinya ketika diterapkan dikelas siswa tidak menemukan kesulitan.

\section{HASIL DAN PEMBAHASAN}

\section{A. Hasil Penelitian}

Penelitian ini dilakukan selama 4 kali pertemuan yang disajikan dalam bentuk siklus, melalui siklus pertama dan siklus kedua. Hasil dari penelitian ini akan diuraikan sebagai berikut:

Sebelum penelitian dilaksanakan, peneliti mengamati kondisi siswa dan proses pembelajaran yang tengah terjadi juga motivasi siswa dalam mengikuti proses pembelajaran . Sebelum tindakan dilaksanakan, terlebih dahulu peneliti mengadakan pre test. Pre test dilaksanakan pada hari selasa tanggal 8 Januari 2019 pada pukul 08.00-09.30 yang bertujuan untuk mengetahui pengetahuan awal siswa, kesiapan dalam belajar, dan mengetahui seberapa besar minat siswa terhadap mata pelajaran Akidah Akhlak pada materi KD Memahami Tasawuf. 
Vol. 1 No. 2 September 2021 e-ISSN : 2797-3344 P-ISSN : 2797-3336

Pada pelaksanaan pre test, siswa terlihat kurang antusias terhadap pelajaran. Mereka terlihat kurang bisa mengikuti kegiatan belajar mengajar dengan baik. Hal itu terlihat dari kurangnya rasa ingin tahu mereka terhadap materi yang akan diberikan. Kebanyakan dari mereka kelihatannya jenuh terhadap pelajaran. Dari hasil evaluasi pada saat pre test, didapatkan rata-rata prestasi belajar kelas sebesar 79

Tabel 1. hasil evaluasi pada saat pre test

\begin{tabular}{|c|c|c|c|}
\hline \multirow[t]{2}{*}{ No } & \multirow[b]{2}{*}{ Nama } & \multicolumn{2}{|c|}{ Pre test } \\
\hline & & $\begin{array}{c}\text { KI 3 } \\
\text { Pengetahuan }\end{array}$ & $\begin{array}{c}\text { KI 4 } \\
\text { Ketrampilan }\end{array}$ \\
\hline 1 & Afi Anti N.J. & 85 & $\mathrm{~B}$ \\
\hline 2 & Nikken D.A. & 78 & $\mathrm{~B}$ \\
\hline 3 & Yayang R.N & 80 & A \\
\hline 4 & Ach. Fadil. S & 78 & B \\
\hline 5 & Dwi Agustin & 78 & B \\
\hline 6 & M. Gegas F. & 78 & $\mathrm{~B}$ \\
\hline 7 & Noer Ita A. & 80 & $\mathrm{~B}$ \\
\hline 8 & Nur Laili & 79 & B \\
\hline 9 & Himatul Kh. & 80 & B \\
\hline 10 & Lailatul M. & 80 & B \\
\hline 11 & M. Afif Mift. & 78 & B \\
\hline 12 & M. Azizi F. & 78 & B \\
\hline 13 & Bejo Sugeng & 78 & $\mathrm{~A}$ \\
\hline 14 & Ferry Hamzah & 78 & $\mathrm{~B}$ \\
\hline 15 & Maghfirotul A. & 80 & B \\
\hline 16 & Indah Rahma & 80 & B \\
\hline 17 & Nika Riyantin & 79 & B \\
\hline 18 & Aditya Yudha S. & 78 & B \\
\hline 19 & Della Mia Vista & 78 & B \\
\hline 20 & Liana Ulandari & 80 & A \\
\hline 21 & Novi Indriyani & 80 & B \\
\hline 22 & Tria Aprilia & 85 & A \\
\hline 23 & Dea. Irma Sri.H & 83 & B \\
\hline 24 & Dia Nirita M. & 80 & A \\
\hline 25 & Ghariza Rizwari & 78 & B \\
\hline 26 & Panji Saka K. & 78 & B \\
\hline 27 & Siti Munikah & 79 & B \\
\hline 28 & Choiril Anhar & 85 & A \\
\hline 29 & Imron & 78 & B \\
\hline 30 & Irna Roud Ch. & 79 & $\mathrm{~B}$ \\
\hline 31 & Mega Setya N. & 78 & $\mathrm{~B}$ \\
\hline 32 & M. Farid A A & 78 & $\mathrm{~B}$ \\
\hline 33 & Taufiqi F. & 78 & $\mathrm{C}$ \\
\hline 34 & Tuhfatul Maula & 80 & $\mathrm{~B}$ \\
\hline 35 & Wahyu Ika R. & 78 & $\mathrm{~B}$ \\
\hline 36 & Verdian Junaidi & 78 & $\mathrm{C}$ \\
\hline \multicolumn{2}{|c|}{ Rata-rata } & 79 & \\
\hline
\end{tabular}

Kemudian dilanjutkan penelitian pada siklus pertama yang hasilnya adalah sebagai berikut 
Vol. 1 No. 2 September 2021 e-ISSN : 2797-3344 P-ISSN : 2797-3336

\section{a. Perencanaan}

Untuk meningkatkan prestasi belajar siswa Kelas XI IPS1 terhadap mata pelajaran Akidah Akhlak KD Memahami Tasawuf. Maka pada siklus yang pertama ini mencoba menerapkan metode Teams Games Tournament.

Tabel. 2. Kegiatan Pembelajaran Pertemuan awal Siklus 1

\begin{tabular}{|c|c|c|}
\hline Kegiatan & Waktu & Karakter yang dikembangkan \\
\hline $\begin{array}{l}\text { Kegiatan Awal : } \\
\text { Apersepsi dan motivasi : } \\
\text { Memberikan salam pembuka, mengajak } \\
\text { berdoa bersama (doa sebelum belajar), } \\
\text { membaca asmaul husna dengan } \\
\text { lantunan indah, perkenalan. } \\
\text { Memotivasi anak-anak untuk } \\
\text { mempelajari materi tasawuf. } \\
\text { Memotivasi anak-anak untuk dapat } \\
\text { meneladani orang yang berperilaku } \\
\text { tasawuf } \\
\text { Kegiatan Inti : } \\
\text { Membagi kelompok, kemudian } \\
\text { memberi waktu untuk mengerjakan } \\
\text { mind mapping atau peta konsep. } \\
\text { Setiap ketua kelompok } \\
\text { mempresentasikan hasil mind } \\
\text { mappingnya. } \\
\text { Guru menjelaskan pengertian tasawuf, } \\
\text { asal usulnya serta menjelaskan } \\
\text { beberapa istilah dalam tasawuf. } \\
\text { Guru mengajak siswa untuk membuat } \\
\text { kesimpulan tentang yang dijelaskan } \\
\text { oleh guru soal tasawuf. }\end{array}$ & $2 \times 45$ menit & $\begin{array}{l}\text { Kritis, rasa ingin tahu, Rasa ingin } \\
\text { tahu, meneladani orang yang } \\
\text { berperilaku tasawuf serta } \\
\text { menerapkannya dalam kehidupan } \\
\text { sehari-hari }\end{array}$ \\
\hline $\begin{array}{l}\text { Kegiatan penutup : } \\
\text { Guru memberikan tes secara lisan } \\
\text { tentang tasawuf. } \\
\text { Memberikan salam penutup }\end{array}$ & & \\
\hline
\end{tabular}

Tabel 3. Kegiatan Pembelajaran Pertemuan Kedua Siklus 1

\begin{tabular}{|c|c|c|}
\hline Kegiatan & Waktu & Karakter yang dikembangkan \\
\hline $\begin{array}{l}\text { Kegiatan Awal : } \\
\text { Apersepsi dan motivasi : } \\
\text { Memberikan salam pembuka, mengajak } \\
\text { berdoa bersama (doa sebelum belajar), } \\
\text { membaca asmaul husna dengan lantunan } \\
\text { indah. } \\
\text { Memotivasi anak-anak untuk } \\
\text { mempelajari fungsi dan peranan tasawuf } \\
\text { dalam kehidupan modern. }\end{array}$ & $\begin{array}{l}2 \times 45 \\
\text { menit }\end{array}$ & $\begin{array}{l}\text { Toleransi, Kritis, rasa ingin tahu, } \\
\text { respek, peduli sosial. }\end{array}$ \\
\hline
\end{tabular}


Vol. 1 No. 2 September 2021 e-ISSN : 2797-3344 P-ISSN : 2797-3336

Memotivasi anak-anak untuk

mempelajari fungsi dan peranan tasawuf dalam kehidupan modern.

Kegiatan Inti :

Guru menjelaskan fungsi dan peranan tasawuf dalam kehidupan modern.

Membagi kelompok, antara 3-4 siswa.

Kemudian memberi soal dengan jawaban

yang sudah di acak lalu siswa

menggabungkan soal dan jawaban di

kertas karton yang sudah disediakan.

Guru mengajak siswa untuk membuat

kesimpulan tentang yang dijelaskan oleh

guru soal tasawuf.

Kegiatan penutup :

Guru memberikan tes secara lisan tentang tasawuf.

Memberikan salam penutup

\section{b. Pelaksanaan}

Pada siklus yang pertama ini dilaksanakan pada pertemuan pertama tepatnya pada hari selasa tanggal 15 Januari 2019 dan tanggal 22 Januari 2019. Apa yang diagendakan berjalan sesuai dengan yang telah direncanakan, yaitu penerapan metode Teams Games Tournament dalam meningkatkan prestasi belajar mata pelajaran Akidah Akhlak KD Memahami Tasawuf, pada siswa Kelas XI IPS1 MAN 1 Jombang.

Ada beberapa Kendala yang dicatat peneliti pada siklus ini, antara lain :

Siswa belum memiliki buku pegangan/buku paket Akidah Akhlak

Siswa masih ramai dan belum bisa berkonsentrasi pada materi

Siswa kurang disiplin dalam mengerjakan tugasnya, yaitu mereka setengah-setengah dalam mengerjakan tugas.

- Siswa sebelumnya tidak belajar terkait materinya, sehingga mereka belum menguasai apa yang akan dipresentasikan.

\section{c. Pengamatan}

Dalam siklus pertama yang terdapat dua pertemuan yang diamati oleh peneliti adalah pada pertemuan pertama siswa masih belum memiliki pedoman Lembar Kerja Siswa atau LKPD (Lembar Kegiatan Peserta Didik), tetapi siswa tetap dapat menggunakan buku paket. Masih terdapat siswa yang ramai dan belum bisa berkonsentrasi ketika pembelajaran berlangsung. Pengamatan dalam pertemuan kedua, ada saja siswa yang kurang disiplin dalam mengerjakan tugas. Siswa juga terlihat tidak menguasai materi ketika presentasi dikarenakan siswa sebelumnya tidak belajar terkait materi yang akan dipresentasikan. Tetapi disini sudah terlihat siswa yang aktif ataupun kurang aktif dalam pembelajaran. Setelah diadakan evaluasi menggunakan ulangan harian kompetensi dasar pertama dan kedua dan hasil nilai siswa ratarata menjadi 84 . Sebagaimana dalam perolehan data berikut :

Tabel 4. Hasil Belajar Siswa pada Pos test Siklus 1

\begin{tabular}{|c|c|c|c|}
\hline \multirow{2}{*}{ No } & \multirow{2}{*}{ Nama } & \multicolumn{2}{|c|}{ Post test 1 } \\
\cline { 3 - 4 } & & $\begin{array}{c}\text { KI 3 } \\
\text { Pengetahuan }\end{array}$ & $\begin{array}{c}\text { KI 4 } \\
\text { Ketrampilan }\end{array}$ \\
\hline 1 & Afi Anti N.J. & 90 & A \\
\hline
\end{tabular}


Vol. 1 No. 2 September 2021 e-ISSN : 2797-3344 P-ISSN : 2797-3336

\begin{tabular}{|c|c|c|c|}
\hline 2 & Nikken D.A. & 78 & A \\
\hline 3 & Yayang R.N & 85 & A \\
\hline 4 & Ach. Fadil. S & 78 & $\mathrm{~B}$ \\
\hline 5 & Dwi Agustin & 80 & $\mathrm{~B}$ \\
\hline 6 & M. Gegas F. & 78 & $\mathrm{~B}$ \\
\hline 7 & Noer Ita A. & 95 & $\mathrm{~B}$ \\
\hline 8 & Nur Laili & 95 & B \\
\hline 9 & Himatul Kh. & 90 & $\mathrm{~B}$ \\
\hline 10 & Lailatul M. & 82.5 & $\mathrm{~B}$ \\
\hline 11 & M. Afif Mift. & 90 & $\mathrm{~B}$ \\
\hline 12 & M. Azizi F. & 80 & $\mathrm{~B}$ \\
\hline 13 & Bejo Sugeng & 78 & $\mathrm{~B}$ \\
\hline 14 & Ferry Hamzah & 90 & B \\
\hline 15 & Maghfirotul A. & 90 & $\mathrm{~B}$ \\
\hline 16 & Indah Rahma & 80 & $\mathrm{~B}$ \\
\hline 17 & Nika Riyantin & 95 & $\mathrm{~B}$ \\
\hline 18 & Aditya Yudha S. & 78 & $\mathrm{~B}$ \\
\hline 19 & Della Mia Vista & 78 & $\mathrm{~B}$ \\
\hline 20 & Liana Ulandari & 80 & A \\
\hline 21 & Novi Indriyani & 90 & $\mathrm{~B}$ \\
\hline 22 & Tria Aprilia & 85 & A \\
\hline 23 & Dea. Irma Sri.H & 95 & A \\
\hline 24 & Dia Nirita M. & 85 & $\mathrm{~A}$ \\
\hline 25 & Ghariza Rizwari & 78 & $\mathrm{~B}$ \\
\hline 26 & Panji Saka K. & 78 & $\mathrm{~A}$ \\
\hline 27 & Siti Munikah & 95 & B \\
\hline 28 & Choiril Anhar & 95 & $\mathrm{~A}$ \\
\hline 29 & Imron & 78 & $\mathrm{~B}$ \\
\hline 30 & Irna Roud Ch. & 85 & $\mathrm{~A}$ \\
\hline 31 & Mega Setya N. & 78 & $\mathrm{~B}$ \\
\hline 32 & M. Farid A A & 78 & $\mathrm{~A}$ \\
\hline 33 & Taufiqi F. & 78 & $\mathrm{~B}$ \\
\hline 34 & Tuhfatul Maula & 80 & $\mathrm{~B}$ \\
\hline 35 & Wahyu Ika R. & 80 & $\mathrm{~B}$ \\
\hline 36 & Verdian Junaidi & 84 & $\mathrm{~B}$ \\
\hline \multicolumn{2}{|c|}{ Rata-rata } & 84 & \\
\hline
\end{tabular}

\section{d. Refleksi}

Dari hasil pengamatan Peneliti ternyata penerapan metode Temas Games Tournament ini bisa dikatakan mempunyai pengaruh terhadap prestasi belajar siswa. Baik dari ranah penilaian KI 3 (Pengetahuan) maupun ranah KI 4 (Ketrampiulan) pada siswa kelas XI IPS1.

Selanjutnya peneliti melakukan siklus yang kedua. Hasilnya sebagai berikut a. Perencanaan

Setelah melihat hasil dari observasi pada siklus yang pertama, peneliti pada siklus yang kedua ini masih tetap akan menggunakan metode Teams Games Tournament, hal ini dikarena peneliti merasa apa yang coba dilakukan ada hasilnya.

Tabel 5. Kegiatan Pembelajaran pertemuan 1 Siklus 2 
Vol. 1 No. 2 September 2021 e-ISSN : 2797-3344 P-ISSN : 2797-3336

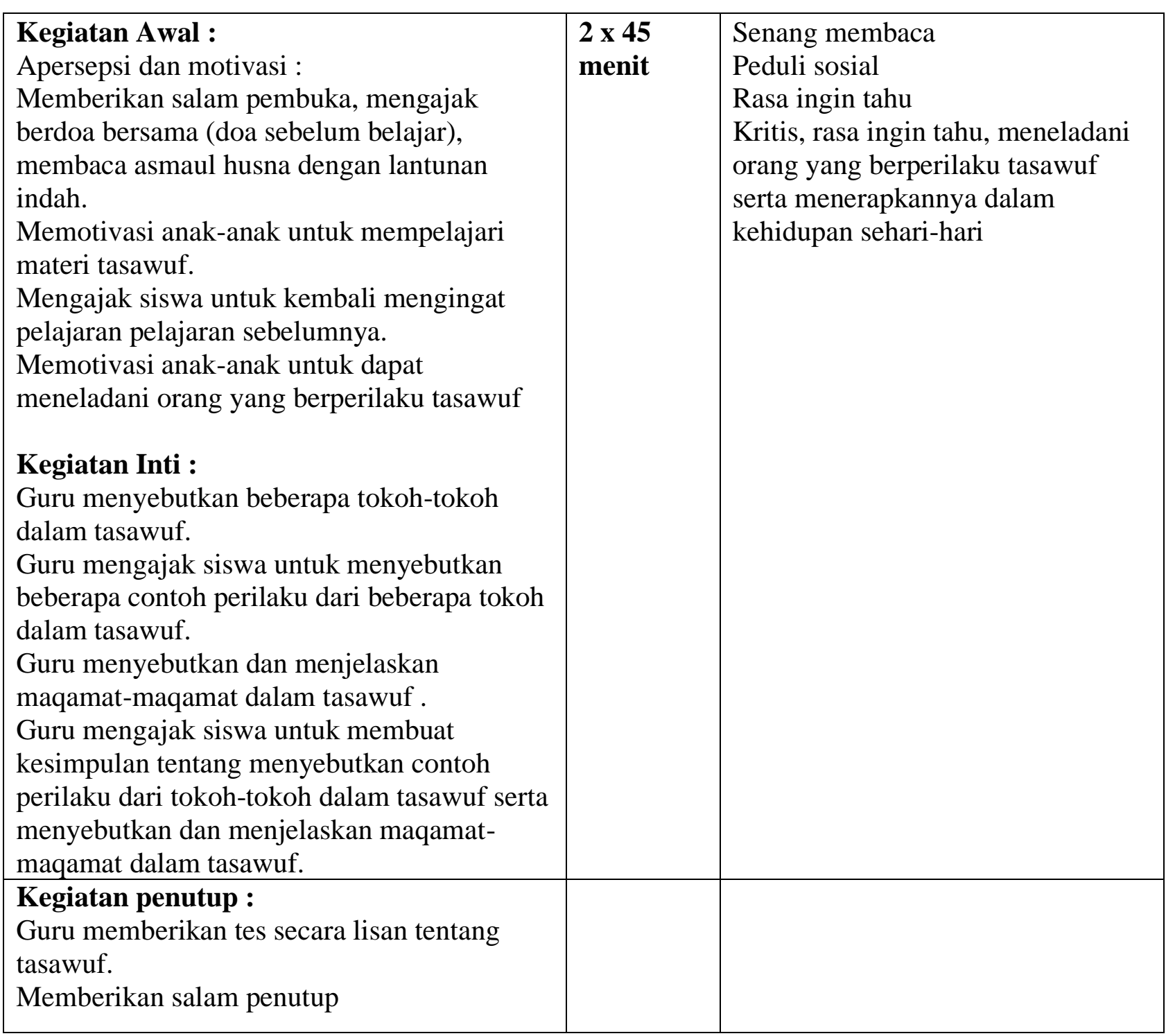

Tabel 6. Kegiatan Pembelajaran pertemuan kedua pada Siklus 2

\begin{tabular}{|c|c|c|}
\hline Kegiatan & Waktu & Karakter yang dikembangkan \\
\hline $\begin{array}{l}\text { Kegiatan Awal : } \\
\text { Apersepsi dan motivasi : } \\
\text { Memberikan salam pembuka, mengajak } \\
\text { berdoa bersama (doa sebelum belajar), } \\
\text { membaca asmaul husna dengan lantunan } \\
\text { indah. } \\
\text { Memotivasi anak-anak untuk mempelajari } \\
\text { materi tasawuf. } \\
\text { Mengajak siswa untuk kembali mengingat } \\
\text { pelajaran sebelumnya. } \\
\text { Memotivasi anak-anak untuk dapat } \\
\text { menunjukkan peran tasawuf dalam } \\
\text { kehidupan modern. } \\
\text { Kegiatan Inti : } \\
\text { Guru membagi kelompok antara 3-4 siswa. } \\
\text { Guru menyebutkan suatu masalah } \\
\text { mengenai problematika masyarakat } \\
\text { modern, kemudian menyuruh siswa untuk }\end{array}$ & $\begin{array}{l}2 \times 45 \\
\text { menit }\end{array}$ & $\begin{array}{l}\text { Senang membaca } \\
\text { Peduli sosial } \\
\text { Rasa ingun tahu Kritis, meneladani } \\
\text { orang yang berperilaku tasawuf serta } \\
\text { menerapkannya dalam kehidupan } \\
\text { sehari-hari }\end{array}$ \\
\hline
\end{tabular}


Vol. 1 No. 2 September 2021 e-ISSN : 2797-3344 P-ISSN : 2797-3336

mencari solusi mengenai problematika tersebut.

Perkelompok menjelaskan solusi dari problematika tersebut.

Guru mengajak siswa membahas problematika masyarakat modern.

Guru mengajak siswa menyebutkan peran tasawuf dalam kehidupan masyarakat modern.

Guru menjelaskan kepada siswa peran tasawuf dalam kehidupan masyarakat modern.

Guru mengajak siswa untuk membuat kesimpulan tentang problematika masyarakat modern beserta solusinya dan peran tasawuf dalam kehidupan masyarakat modern.

\section{Kegiatan penutup :}

Guru memberikan tes secara lisan tentang problematika masyarakat modern beserta solusinya dan peran tasawuf dalam kehidupan masyarakat modern.

Memberikan salam penutup

\section{b. Pelaksanaan}

Pada siklus yang kedua ini yang awalnya peneliti merencanakan hanya 2 pertemuan, ternyata setelah memasuki lapangan penelitian pada siklus kedua ini menjadi 3 pertemuan. Pertemuan itu dilaksanakan dari pertemuan ketiga yang dimulai tepatnya pada hari kamis tanggal 29 Januari 2019, 12 Februari 2019, dan 19 Februari 2019. Apa yang direncanakan berjalan dengan lancar pada awal pertemuan sampai akhir, karena pada awal hingga akhir pertemuan keaktifan siswa semakin meningkat dan keaktifan tersebut berpengaruh besar terhadap prestasi belajar siswa.

\section{c. Pengamatan}

Pada Siklus yang kedua ini Peneliti mencoba lebih mengoptimalkan lagi tentang penerapan Metode Teams Games Tournament dan setelah dilakukan evaluasi nilai siswa semakin meningkat khususnya pada mata pelajaran Akidah Akhlak dengan hasil akhir rata-rata 95 .

Tabel 7. Hasil Belajar Siswa pada Pos test Siklus 2

\begin{tabular}{|c|l|c|c|}
\hline \multirow{2}{*}{ No } & \multirow{2}{*}{ Nama } & \multicolumn{2}{c|}{ Post test 2 } \\
\cline { 3 - 4 } & & Kognitif & Psikomotor \\
\hline 1 & Afi Anti Nur Jannah & 87,5 & $\mathrm{~A}$ \\
\hline 2 & Nikken Dewi Anggraini & 87,5 & $\mathrm{~B}$ \\
\hline 3 & Yayang Rohmatun Nafila & 87,5 & $\mathrm{~A}$ \\
\hline 4 & Achmad Fadil S & 100 & $\mathrm{~A}$ \\
\hline 5 & Dwi Agustin & 80 & $\mathrm{~A}$ \\
\hline 6 & M. Gegas Firdaus & 100 & $\mathrm{~B}$ \\
\hline 7 & Noer Ita Anggreini & 100 & $\mathrm{~B}$ \\
\hline 8 & Nur Laili & 100 & $\mathrm{~B}$ \\
\hline
\end{tabular}


PAEDAGOGY : Jurnal IImu Pendidikan dan Psikologi

Vol. 1 No. 2 September 2021 e-ISSN : 2797-3344 P-ISSN : 2797-3336

\begin{tabular}{|c|l|c|c|}
\hline 9 & Himatul Kholisoh & 87,5 & B \\
\hline 10 & Lailatul Maisaroh & 95 & B \\
\hline 11 & M. Afif Miftakhullah & 87,5 & B \\
\hline 12 & Muhammad Azizi Firdaus & 82,5 & A \\
\hline 13 & Bejo Sugeng & 100 & B \\
\hline 14 & Ferry Hamzah & 95 & B \\
\hline 15 & Maghfirotul Akhiroh & 89 & A \\
\hline 16 & Indah Rahmawati & 100 & A \\
\hline 17 & Nika Riyantin & 87,5 & A \\
\hline 18 & Aditya Yudha Sakti & 82,5 & B \\
\hline 19 & Della Mia Vista & 100 & A \\
\hline 20 & Liana Ulandari & 87,5 & A \\
\hline 21 & Novi Indriyani & 100 & A \\
\hline 22 & Tria Aprilia & 100 & A \\
\hline 23 & Dea. Irma Sri.H & 87,5 & A \\
\hline 24 & Dia Nirita Melawati & 95 & A \\
\hline 25 & Ghariza Rizwari & 100 & A \\
\hline 26 & Panji Saka K. & 100 & B \\
\hline 27 & Siti Munikah & 100 & B \\
\hline 28 & Choiril Anhar & 95 & A \\
\hline 29 & Imron & 100 & B \\
\hline 30 & Irna Roudhotul Ch. & 100 & A \\
\hline 31 & Mega S. Ningrum & 87,5 & A \\
\hline 32 & Mohammad Farid A A & 95 & A \\
\hline 33 & Taufiqi Fakkarudin & 78 & B \\
\hline 34 & Tuhfatul Maula & 100 & B \\
\hline 35 & Wahyu Ika Riskianti & 78,5 & 95 \\
\hline 36 & Verdian Junaidi & & \\
\hline & & Rata-rata & \\
\hline
\end{tabular}

Selanjutnya disajikan ringkasan hasil penelitian dari pre test dan post tes yang dilakukan pada siklus 1 dan siklus 2, sebagaimana dalam tabel berikut :

\section{GRAFIK NILAI RATA-RATA KELAS}

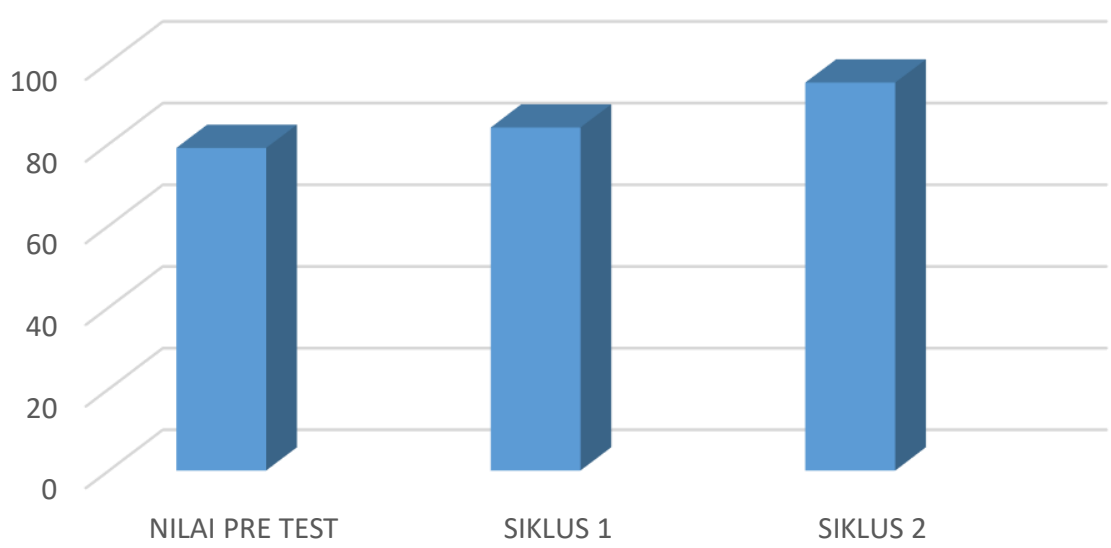

Gambar 2. Grafik Nilai Rata-rata Kelas 


\section{B. Pembahasan}

Dalam proses kegiatan belajar mengajar tentunya bukan hanya mentransformasikan ilmu pengetahuan saja dengan metode pembelajaran ceramah (tradisional), akan tetapi pemberian semangat dengan kreatifitas game sangatlah penting karena secara psikologis anak akan merasa senang apabila mereka diperhatikan. Salah satu cara memberikan perhatian adalah dengan memotivasi dan memberi inovasi dalam sebuah Metode pembelajaran.

Cooperative learning adalah suatu metode pembelajaran yang berfokus pada penggunaan kelompok kecil peserta didik untuk bekerjasama dalam memaksimalkan kondisi belajar untuk mencapai tujuan belajar. Proses kerjasama dalam kelompok, menurut Syahraini Tambak dalam Jurnal Al Hikmah (2017) terjadi ketika anggota kelompok mendiskusikan seberapa baik mereka mencapai tujuan dan memelihara kerjasama yang efektif. Sedangkan pembelajaran kooperatif model TGT (Team Game Tournamen), menurut Kiranawati (2007) adalah salah satu tipe atau model pembelajaran kooperatif yang mudah diterapkan, melibatkan aktivitas se luruh siswa tanpa harus ada perbedaan status, melibatkan peran siswa sebagai tutor sebaya dan mengandung unsur permainan dan reinfocement. Sehingga memungkinkan siswa belajar lebih rileks disamping menumbuhkan tanggung jawab, kerjasama, persaingan sehat dan keterlibatan siswa. Metode ini juga sangat cocok diterapkan kepada siswa yang memiliki karakteristik sebagaimana siswa/siswi kelas XI IPS1 MAN 1 Jombang, begitu juga dengan karakteristik materi Aqidah Akhlak KD Memahami Tasawuf yang diajarkan oleh guru.

Penelitian ini dilatarbelakangi oleh pengalaman dalam mengajar Aqidah Akhlak pada KD Memahami Tasawuf pada tahun-tahun sebelumnya. Yang menunjukkan hasil kurang memuaskan, prestasi belajar siswa masih rata-rata dibawah KKM atau pas pada standar KKM. Pada tabel 8 dengan jelas digambarkan progres dari penerapan strategi pembelajaran Kooperatif dengan metode Teams Games Tournament, dengan hasil yang dapat didiskripsikan sebagai berikut: Post test diperoleh nilai rata-rata kelas 79, pada siklus 1setelah dilakukan post test diperoleh nilai rata-rata 84 , sedang pada siklus 2 setelah post test diperoleh nilai rata-rata 95 . Maka berdasarkan hasil penelitian yang telah dilakukan pada siklus I dan II dapat dikatakan bahwa terdapat peningkatan prestasi belajar siswa baik secara individu maupun kelompok. Secara umum dapat dikatakan bahwa penerapan strategi pembelajaran Kooperatif dengan metode TGT (Teams Games Tournament) pada mata pelajaran Aqidah Akhlak materi Tasawuf, terbukti efektif dalam meningkatkan prestasi belajar siswa. Hal ini sesuai dengan hasil penelitian yang dilakukan oleh Widhiastuti dalam Jurnal Pendidikan Ekonomi Dinamika Pendidikan Vol.IX; 2014 yang menyatakan bahwa model belajar mengajar Teams Games Tournament yang dikembangkan oleh Robert Slavin merupakan teknik belajar dengan menggabungkan kelompok belajar dengan kompetisi tim, dan bisa digunakan untuk meningkatkan pembelajaran beragam fakta, konsep dan ketrampilan.

Dalam model pembelajaran kooperatif tipe TGT (Teams Games Tournament), kerjasama tim sangat diutamakan. Terlebih lagi dengan adanya penghargaan bagi tim yang paling efektif yang memperoleh skor tertinggi. Hal tersebut tentu saja mendorong seluruh anggota tim untuk aktif menjawab, menanggapi maupun menjawab. Dengan begitu secara otomatis nilai/perstasi belajar merekapun menjadi meningkat. Berbeda dengan metode ceramah dan pemberian tugas, yang selama ini masih sering digunakan oleh beberapa guru pada beberapa mata pelajaran termasuk Pendidikan Agama Islam, cenderung masih tradisional, materi bersifat hafalan, penyampaian informasi kurang efektif, karena tidak adanya penguatan daya ingat atau pemahaman. Pencapaianketuntasa belajar siswa pun masih belum tercapai secara maksimal.

Ketuntasan pembelajaran dapat tercapai dikarenakan adanya keterlibatan guru atau pendekatan guru kepada siswa untuk menanyakan kesulitan dalam mengerjakan soal-soal. Kesuksesan belajar siswa tidak hanya tergantung pada intelegensi anak saja, akan tetapi juga tergantung pada bagaimana pendidik menggunakan metode yang tepat dan memberinya motivasi. Sebagaimana dikemukakan oleh Sudjana (2002: 1-2) ada tiga variabel utama yang saling berkaitan dalam strategi pelaksanaan pendidikan di sekolah. Dan tentunya berpengaruh kuat terhadap ketuntasan belajar siswa. Ketiga variabel tersebut adalah kurikulum, guru, dan 


\section{Vol. 1 No. 2 September 2021 e-ISSN : 2797-3344 P-ISSN : 2797-3336}

pengajaran atau proses belajar mengajar. Kurikulum dipandang/diartikan sebagai program belajar bagi siswa (plan for learning) yang disusun secara sistematik, dan diberikan oleh lembaga pendidikan tertentu untuk mencapai tujuan pendidikan. Atas dasar itulah ada pandangan yang menyatakan bahwa kurikulum tidak lain adalah hasil belajar yang diniati/diharapkan atau intended learning out come. Guru menempati kedudukan sentral sebab peranannya sangat menentukan. Ia harus mampu menterjemahkan dan menjabarkan nilai-nilai yang terdapat dalam kurikulum, kemudian mentransformasikan nilai-nilai tersebut kepada siswa melalui proses pengajaran di sekolah.

Banyak cara yang dapat dilakukan untuk memberikan inovasi pembelajran kepada anak didik diantaranya adalah memberi angka atau nilai. Pemberian mulai dilakukan oleh guru ketika mereka selesai ulangan atau menjawab pertanyaan yang diberikan oleh guru. Cara ini merangsang anak untuk giat belajar. Anak yang nilainya rendah, mereka akan membangkitkan minat belajarnya dan anak yang nilainya bagus akan semakin giat dalam belajar. Nilai yang bagus dan giatnya siswa dalam belajar merupakan inti dari meningkatnya prestasi belajar siswa.

Prestasi adalah hasil dari suatu kegiatan yang telah dikerjakan, diciptakan baik secara individu maupun kelompok. Ada beberapa pendapat mengenai pengertian prestasi belajar diantaranya adalah:

1. Poerwanto (2007) memberikan pengertian prestasi belajar yaitu " hasil yang dicapai oleh seseorang dalam usaha belajar sebagaimana yang dinyatakan dalam rapot"

2. Sedangkan menurut Nasrun Harahap dan kawan-kawan memberi batasan bahwa prestasi adalah penilaian pendidikan tentang perkembangan dan kemajuan murid yang berkenaan dengan penguasaan bahan pelajaran yang disajikan kepada mereka serta nilai yang terdapat dalam kurikulum.

Pengertian prestasi yang dikemukakan para ahli diatas, mempunyai inti yang sama yaitu hasil yang dicapai dari suatu kegiatan. Jadi dapat disimpulkan bahwa prestasi belajar adalah sebuah hasil dari kegiatan mengkaji ilmu pengetahuan hingga mencapai satu titik pemahaman tertentu yang dikemukakan dalam bentuk angka, huruf, atau kata-kata baik, sedang, kurang dan sebagainya, seperti tertera dalam laporan hasil belajar siswa atau lebih terkenal dengan sebutan Rapot.

Prestasi belajar dalam pendidikan agam Islam, dapat dilihat ketika peserta didik dapat mengenal, memahami, menghayati, sehingga mengimani ajaran-ajaran agama Islam lalu kemudian mengaplikasikannya dalam kehidupan sehari-hari. Dan pada KD Memahami Tasawuf ini, tentunya diharapkan siwa tidak hanya memahami pengertian tasawuf, melainkan juga mampu menjadi manusia yang berakhlakul karimah sebagaimana terdapat pada hakikat dan tujuan tasawuf.

Ada berbagai upaya dalam meningkatkan prestasi belajar siswa

a. Tujuan menunjukan arah dari suau usaha, sedangkan arah menunjukan jalan yang harus ditempuh. Setiap kegiatan mempunyai tujuan tertentu karena berhasil tidaknya suatu kegiatan diukur sejauh mana kegiatan tersebut mencapai tujuannya.

b. Metode dan alat

Dalam proses belajar mengajar, metode merupakan komponen yang ikut menentukan berhasil atau tidaknya program pengajaran dan tujuan pendidikan. Adapun pengertian metode adalah suatu cara yang dilakukan dengan fungsinya merupakan alat untuk mencapai suatu tujuan.

c. Bahan atau materi

Dalam pemilihan materi atau bahan oengajaran yang akan diajarkan disesuaikan dengan kemampuan sisw yang selalu berpedoman pada tujuan yang ditetapkan. Karena dengan kegiatan belajar mengajar merumuskan tujuan, setelah tujuan dapat diketahui, kemudian baru menetapkan materi. Setelah materi ditetapkan guru dapat menentukan metode yang akan dipakai dalam menyampaikan materi tersebut. 


\section{Vol. 1 No. 2 September 2021 e-ISSN : 2797-3344 P-ISSN : 2797-3336}

Pada penelitian ini peneliti sudah membuktikan berdasarkan observasi melalui siklussiklus yang dilakukan bahwa ternyata Salah satu tipe atau model yang dapat dipakai untuk mencapai keberhasilan dalam kegiatan pembelajaran, danb mampu meningkatkan prestasi belajar siswa adalah Teams Games Tournament yang merupakan salah satu variasi model cooperative learning.

\section{KESIMPULAN}

Dari paparan diatas dapat disimpulkan :

1. Perencanaan dan pelaksanaan pembelajaran dengan metode Cooperative learning dengan tipe teams games tournament, untuk meningkatkan prestasi belajar siswa kelas XI IPS1 MAN 1 Jombang, mata pelajaran Akidah Akhlak KD Memahami Tasawuf, mulai dari pembentukan kelompok, menyusun soal pre test dan post test yang akan diberikan pada akhir setiap siklus, serta menyiapkan media dan sumber belajar yang diperlukan.

2. Model pembelajaran cooperative learning melalui tipe TGT (Teams Games Tournaments)sangat tepat digunakan untuk materi Memahami Tasawuf, aktifitas belajar siswa meningkat dan pola pikir anak terbentuk dalam menyelesaikan suatu permasalahan yang diajukan sehingga ketuntasan belajar siswa dapat dicapai.

\section{DAFTAR PUSTAKA}

Ahmadi, Abu dan Joko Tri Prasetya. (2005). Strategi Belajar Mengajar. Bandung : Pustaka Setia.

Eggen, Paul \& Don Kauchak. (2012). Strtegi dan model pembelajaran. Jakarta : Indeks.

Isjoni. (2009) Cooperative learning, mengembangkan kemampuan belajar Kelompok.

Kiranawati. (2007). Model Teams Games Tournament, Tersedia pada http://Kiranawati.blog.woodpress.com.Diakses pada tanggal 26 Mei 2012

Mustofa, A. (2005). Akhlak Tasawuf. Bandung, CV Pustaka Setia

Poerwadarminta, Ngalim. (2007). Psikologi Pendidikan, Bandung, PT Rosda Karya

Sanjaya, Wina. (2008). Strategi Pembelaaran Berorientasi Standar Proses Pendidikan, Jakarta, Kencana Prenada Media Group

Slavin Robert E. (2010). Cooperative learning. London : Allymand Bacon.

Sudjana, Nana. (2009). Dasar-dasar proses belajar mengajar. Bandung: Sinar Baru

Tambak, Syahraini. (2017). Metode Cooperatif Learning Dalam Pembelajaran Pendidikan Agama Islam. Jurnal Al Hikmah, Vol 14, 1 April 2017

Undang-undang Republik Indonesia nomor 20 tahun 2003. 2006. Sistem Pendidikan Nasional. Bandung : Fokus Media.

Usman, M. Basyiruddin.(2002). Metodologi Pembelajaran Agama Islam. Jakarta : Ciputat Pers. Usman, Ida Inayahwati. (2017). Ayo Mengkaji Akidah Akhlak. Jakarta, Erlangga

Wahidmurni, dan Nur Ali (2008), Penelitian Tindakan Kelas, Pendidikan Agama dan Umum dari Teori Menuju Praktik. UM Press Malang

Widhiastuti, Ratieh dan Fahrurrozi. (2014). Teams Games Tournament (TGT) Sebagai Metode Untuk Meningkatkan Kreatifitas Dan Kemampuan Belajar. Jurnal Pendidikan Ekonomi Dinamika Pendidikan Volume IX, 1 Juni 2014 Halaman 48-56 